http://dx.doi.org/10.18778/0208-6050.95.12

MiROSŁAW ROMAŃSKI

(RZESZOW)

\title{
Sytuacja społeczno-polityczna w okresie powstania muru berlińskiego według polskich przekazów prasowych
}

System komunistyczny z politycznymi podziałami wytworzonymi przez niego po zakończeniu II wojny światowej miał swoją symbolikę. Miała ona przypominać o jego sile i wykazać jego (na ogół pozorną) wyższość nad pozostałymi ustrojami. Dla niektórych jednak symbole owe stały się obiektem trwania w komunizmie, dla innych stanowiły obszar, z którym podejmowano regularną walkę. $\mathrm{W}$ niektórych przypadkach przebiegała ona sprawnie, w innych trzeba było wielu lat, by usunąc z przestrzeni publicznej symbole utrwalające komunizm. Jednym $\mathrm{z}$ nich był mur berliński, będący bodajże najbardziej okazałą budowlą symbolizującą reżim. Przez niemal 30 lat oddzielał on Niemcy Wschodnie od Zachodnich (więc i Berlin), stając się symbolem podziałów między światem zachodnim a wschodnim.

$\mathrm{Na}$ temat powstania muru berlińskiego nie opublikowano wiele tekstów de facto większość autorów drobnych i szerszych prac koncentruje się na jego upadku. Z tego względu w artykule postanowiono odejść od tego tematu i skoncentrować wątek przewodni na okresie budowy muru berlińskiego oraz sytuacji w pierwszych latach po jego powstaniu. Jednak zasadniczym celem tekstu jest przedstawienie sytuacji społeczno-politycznej w świetle artykułów prasowych analizowanego okresu. Istotnym celem jest też pokazanie mechanizmów propagandowych używanych do kształtowania opinii publicznej, manipulowania faktami, reakcji prasy polskiej wydawanej w PRL na powstanie muru, stosunku do omawianego wydarzenia, a także stylu postrzegania i przedstawiania faktów z życia społeczno-politycznego Niemiec. Istotną częścią tej propagandy było prezentowanie wzajemnych relacji między NRD a RFN.

W największym w historii ogólnonarodowym konflikcie zbrojnym, w II wojnie światowej, uczestniczyło 60 państw, czyli dwa razy więcej niż w I wojnie światowej. Zadecydował o tym charakter wojny, której walki toczyły się na obszarach dobrze zurbanizowanych. Charakterystyczne dla tego konfliktu masowe zbrodnie pochłonęły miliony istnień ludzkich. Do najważniejszych państw stosujących taką politykę należały III Rzesza, Japonia i ZSRR. W wojnie uczestniczyło 
łącznie 1,7 mld osób. Dane szacunkowe mówią, że życie straciło w niej co najmniej 60 mln ludzi. Najważniejszymi przyczynami wojny były dążenia III Rzeszy Niemieckiej i ZSRR do hegemonii na terenie Europy. Ta miała się dokonać przez obalenie porządku międzynarodowego ustanowionego w Wersalu. Przyczyną II wojny światowej były też ambicje sojuszników III Rzeszy - Włoch i Japonii - do uczestnictwa w zrewidowanym na swoją korzyść międzynarodowym układzie sił kosztem mocarstw demokratycznych: Anglii, Francji i USA ${ }^{1}$. W wojnie tej sukces odnieśli alianci, rolę dominującą zyskały USA oraz ZSRR, utworzono ONZ, obalono faszyzm w Europie i Azji Wschodniej ${ }^{2}$ oraz nazizm w Niemczech i Austrii. Podzielono również kraje Europy na Zachód kontrolowany przez USA, Anglię i Francję, a także na Wschód podporządkowany ZSRR ${ }^{3}$.

Ogólnonarodowy konflikt, trwający od 1 września 1939 r. do 8 maja 1945 r. w Europie i do 2 września 1945 r. na świecie, zakończył się totalną klęską III Rzeszy Niemieckiej ${ }^{4}$. W pierwszych latach po wojnie na jej terenach (podzielonych na strefy okupacyjne) powstały dwa państwa: Republika Federalna Niemiec 8 maja 1949 r. (RFN) $)^{5}$ ze stolicą w Bonn oraz Niemiecka Republika Demokratyczna (NRD) 7 października 1949 r. ze stolicą w Berlinie ${ }^{6}$. Oba kraje miały zupełnie odmienną sytuację ekonomiczną, wojskową i polityczną. O ile RFN była rozwinięta pod względem poziomu i dynamiki rozwoju gospodarczego, to powstanie NRD było reakcją ZSRR na utworzenie demokratycznego RFN i miało charakter państwa komunistycznego, zapóźnionego rozwojowo wobec swego zachodniego sąsiada ${ }^{7}$. Nic zatem dziwnego, że określenie „republika demokratyczna" było tylko fasadą, za którą skrywano rzeczywisty kształt ustroju tego państwa ${ }^{8}$.

Od momentu powstania NRD wielu obywateli Niemiec dostrzegło spore różnice w poziomie życia między RFN a NRD. Z tego powodu powszechne stały się masowe ucieczki z Berlina i NRD do demokratycznej RFN. W latach 1949-1961 z NRD łącznie uciekło około 2,6 mln osób. Władze NRD myślały o tym, żeby umocnić swoje granice i wprowadzić w życie radykalne środki blokady w postaci wybudowania specjalnego muru. Propaganda wschodnia zaczęła na łamach prasy

${ }^{1}$ N. D a vi e s, Europa Walczy 1939-1945. Nie takie proste zwycięstwo, Kraków 2008, s. 34-70.

${ }^{2} \mathrm{Z}$ wyjątkiem Hiszpanii i Portugalii.

${ }^{3}$ C. S tre it, Keine Kameraden: Die Wehrmacht und die sowjetischen Kriegsgefangenen 1941-1945, Bonn 1997, s. 10-23.

${ }^{4}$ K. N a d o 1 s k i, Demony wojny, „Wprost”, 26 VIII 2014, s. 72-73.

${ }^{5}$ D. J a n i c k a, Ustawa zasadnicza w praktyce Republiki Federalnej Niemiec (1949-1989), Toruń 2009, s. 8-14.

${ }^{6}$ S. N a r u s z e w i c z, Konrad Adenauer - kanclerz i Europejczyk, Białystok 2004, s. 14-21 i inne.

${ }^{7}$ Encyklopedia historii świata dla catej rodziny, Warszawa 2002, s. 411.

${ }^{8} \mathrm{R}$. W i t e k, Mur - o historii powojennego Berlina, Warszawa 2014, s. 15-24; RFN, NRD, $P R L-z b l i z ̇ e n i a$, red. K. Ruchniewicz, D. Wojtaszyn, Wrocław 2014, s. 7-14. 
nagłaśniać, że chodzi o umocnienia przeciwko siłom NATO, ale mur berliński miał być de facto desperacką próbą zatrzymania fali ucieczek na Zachód ${ }^{9}$. Wystarczyło to, by z inicjatywy władz socjalistycznego NRD rozpocząć budowę muru uniemożliwiającego przedostawanie się obywateli do Berlina Zachodniego. Intensywne prace realizowane latem $1961 \mathrm{r}$. sprawiły, że z liczby 2,6 mln osób, które uciekły z NRD, tylko w pierwszej połowie sierpnia, przed zakończeniem prac nad murem, 47,4 tys. osób nielegalnie przekroczyło granicę ${ }^{10}$.

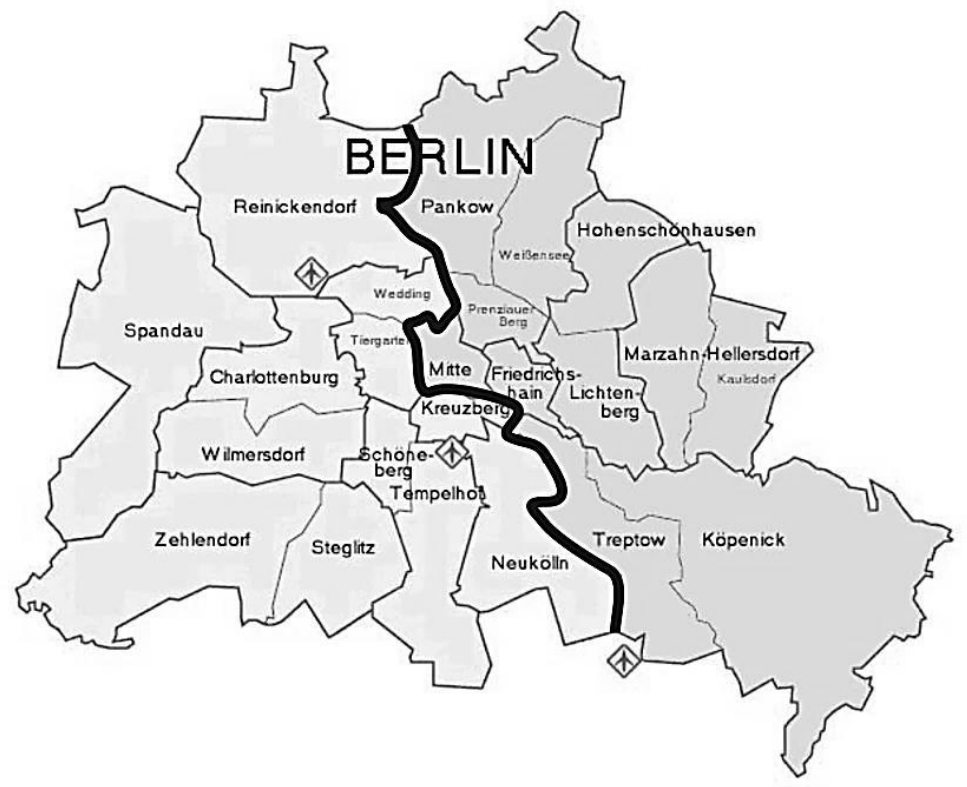

$\mathrm{M}$ a p a 1. Mur berliński jako granica podziału

Źr ó d ło: http://www.dw.de/berlin-wa\%C5\%82\%C4\%99sa-znowu-obali-mur/a-4834118.

Powstanie muru berlińskiego dokonywało się oczywiście w ścisłej tajemnicy władz NRD. Budowano go na polecenie kierownictwa partii SED pod nadzorem policji i żołnierzy Narodowej Armii Ludowej ${ }^{11}$. Ogół działań był w sumie sprzeczny wobec gwarancji przewodniczącego Rady Państwa NRD Waltera Ulbrichta, który 15 czerwca 1961 r. na konferencji prasowej w Berlinie Wschodnim powiedział, że nikt nie ma zamiaru stawiać muru ${ }^{12}$. Ulbricht był pierwszą osobą,

${ }^{9}$ P. Fe is t, Die Berliner Mauer. Der historische Ort. Bd 38. Kai Homilius, Berlin 2004, s. $66-71$.

${ }^{10}$ Mur berliński, „Dodatek do Gazety Wyborczej” 2010, nr 261 (materiał audiowizualny).

${ }^{11}$ J. H e r t 1 e, Mauerbau und Mauerfall, Berlin 2002, s. 101-104.

${ }^{12}$ T. Fl e m m in g, H. K o c h, Die Berliner Mauer. Geschichte lines politischen Bauwerks, Berlin 2001, s. 88-96. 
która użyła określenia „mur berliński”, zanim go wybudowano ${ }^{13}$. Podczas jego budowy w dalszym ciągu odbywały się ucieczki z terenu NRD wszystkimi możliwymi metodami, nawet przez okna domów znajdujących się przy granicy ${ }^{14}$.

Budowę muru berlińskiego rozpoczęto 16 sierpnia $1961 \mathrm{r}$. Reakcja mocarstw zachodnich była na ogół powściągliwa. Po kilkudziesięciu godzinach od rozpoczęcia prac budowlanych siłą rzeczy wystosowano formalne protesty do ZSRR ${ }^{15}$. Dla przykładu, prezydent USA John F. Kennedy powiedział, że mur nie stanowi rozwiązania szczególnie pięknego, ale jest tysiąc razy lepszy niż wojna ${ }^{16}$. Reakcje społeczne w RFN na powstanie muru berlińskiego były niechętne. Dominowało przekonanie o separacji Niemiec wynikającej z podziałów politycznych między RFN - krajem demokratycznym - a NRD - państwem komunistycznym. Nastawianie obywateli do tej sytuacji wcale nie umniejszało chęci do ucieczki pozostałych na terenie NRD Niemców niegodzących się z zaistniałym stanem rzeczy. Solidny mur berliński nie był jednak od tej pory już tak łatwy do pokonania ${ }^{17}$. Oczywiste jest zatem, że liczba ucieczek znacznie się ograniczyła, a niektórzy z uciekinierów stracili nawet życie. Zdaniem prokuratury federalnej 86 osób zginęło $\mathrm{z}$ powodu zastosowania wobec nich przemocy podczas nielegalnego przekraczania granicy. Centrum Badań Historycznych w Poczdamie doliczyło się natomiast 125 ofiar, a wspólnota robocza „13 sierpnia” aż 227. Liczba ta jednak przez wielu jest podawana w wątpliwość jako wyolbrzymiona ${ }^{18}$.

Sporym poruszeniem społeczeństwa zarówno Niemiec Zachodnich, jak Wschodnich było niedowierzanie i zaskoczenie rozmiarem muru, a także akcją zrealizowaną z zaskoczenia i na ogromną skalę. Nie powstrzymywano się od dość ostrych komentarzy, ale te były automatycznie „wyprostowywane” przez socjalistyczną prasę ${ }^{19}$. Dominacja propagandy uznającej mur za słuszne posunięcie miała przełamać krytykę społeczną i skierować uwagę obywateli na sprawy poboczne i codzienne. Takie działania władzom NRD nie wychodziły, gdyż

${ }^{13}$ M. W e i 1, Oryginalny dźwięk. Zimna wojna $w$ eterze, Ilustracja dźwiękowa do wystawy w Centrum Badań Berlińskich, Berlin 1997.

${ }^{14}$ K. L i p o w s k i, Żyć i umrzeć w Berlinie, „Bliza” 2014, nr 1, s. 114-119.

${ }^{15} \mathrm{~A}$. H of $\mathrm{fm}$ a n n, M. H of $\mathrm{fm}$ a n n, Die Mauer - Touren entlang der ehemaligen Grenze, Berlin 2003, s. 234-237.

${ }^{16}$ W. R o t t, Wyspa - dzieje Berlina Zachodniego 1948-1990, Warszawa 2011, s. 222-230; A. K 1 a u s me i e r, L. S c h mid t, Mauerreste - Mauerspuren. Westkreuz, Berlin-Bonn 2004, s. 77-79.

${ }^{17}$ W. R o t t, Wyspa - dzieje Berlina Zachodniego 1948-1990, Warszawa 2011, s. 222-230; A. K 1 a u s me i e r, L. S c h mi d t, Mauerreste - Mauerspuren. Westkreuz, Berlin-Bonn 2004, s. $77-79$.

${ }^{18}$ J. Tre n kn e r, W. T e m p l i n, B. Ke r s k i, Berlin Zachodni, Berlin Wschodni, Berlinszkice i rozmowa o stolicy Niemiec, Szczecin 2003, s. 88-94.

19 J. Rühle, G. Holzweißig, 13. August 1961 - Die Mauer von Berlin. Edition Deutschland Archiv, Köln 1988, s. 116-123. 
świadomi sytuacji obywatele dobrze zdawali sobie sprawę, że informacje pochodzące z prasy i środków masowego przekazu należy traktować z rezerwą i nie odbierać ich w sposób dosłowny.

W Polsce obywatele oficjalnie nie zostali poinformowani o powstaniu muru berlińskiego. Wiadomości takie rozchodziły się drogą nieoficjalną. W prasie PRL i innych środkach masowego przekazu nie podano ani jednej informacji mówiącej, że wybudowano mur. Ich uwaga była ukierunkowana na inne sprawy, co było celowe, i tak usiłowano zwrócić uwagę obywateli na codzienne i przyziemne sprawy. W społeczeństwie polskim w reakcji na powstanie muru pojawiały się też radykalne zachowania. Jednym $\mathrm{z}$ nich była próba uprowadzenia cywilnego samolotu z żądaniem porywaczy skierowania go na lotnisko w Berlinie Zachodnim.

Powstanie muru wzmogło w PRL różne formy oporu społecznego, z których do najczęstszych należało rozpowszechnianie druków ulotnych, plakatów i napisów krytykujących powstanie muru i NRD. Elementem oporu społecznego było także nasilające się od połowy sierpnia 1961 r. rozsyłanie anonimów do przedstawicieli władz państwowych PRL. Podobnie wyglądała sytuacja wśród obywateli reszty państw bloku wschodniego ${ }^{20}$.

Prasa społeczno-polityczna PRL odgrywała dość specyficzną rolę. Adresowana do obywateli miała na celu wywołać w nich poczucie wiedzy o istotnych sprawach i problemach społecznych, ale w żadnym wypadku o polityce. Ta była zarezerwowana dla określonych przedstawicieli państwa, którzy mieli najlepiej wiedzieć, jak reprezentować interesy PRL. Z prasy ogólnodostępnej obywatele dowiadywali się o planach i zamiarach władz, ale nigdy nie mogli otrzymać $\mathrm{w}$ pełni naturalnego i rzeczywistego obrazu ich realizacji. Mowa tu przede wszystkim o wzmiankach na temat braku akceptacji społecznej polityki prowadzonej przez władze PRL. W tym czasie cenzura była całkowicie uzależniona od władz i została zobligowana do tego, aby stać na straży tego, co powinno się przedostawać do świadomości społecznej, a co nie. Funkcjonowanie takiego stylu było podstawą kształtowania i wpływu na opinię publiczną ${ }^{21}$.

W okresie powstawania muru berlińskiego na terenie PRL wydawano około 30 tytułów prasy poruszającej problematykę społeczno-polityczną. Miały one zasięg lokalny i ogólnokrajowy. Mimo sporej ich liczby schemat funkcjonowania pozostawał przeważnie taki sam. Stanowiły one dla władz Polski najważniejszy nośnik propagandy mającej wykazać wyższość ustroju socjalistycznego nad innymi. Lektura prasy polskiej z lat sześćdziesiątych potwierdza, że tytuły te co

${ }^{20}$ M. R o m a ń s k i, Radykalne postawy społeczne w Polsce 1944/45-1990, Rzeszów 2016, s. 190.

${ }^{21}$ A. S z a ł a g a n, Cenzura PRL-owska we wspomnieniach profesor Jadwigi Czachowskiej, „Sztuka Edycji - Studia Tekstologiczne i Edytorskie” 2015, nr 1, s. 89-94. 
prawda informowały o różnych wydarzeniach społeczno-politycznych, ale niekoniecznie przedstawiały ich rzeczywisty obraz. Przeinaczenia, dezorientacja, popieranie przesłanek socjalistycznych i wykazywanie ich wyższości były nagminne. Żeby to zagwarantować, każda $\mathrm{z}$ redakcji poddawana była okresowo wnikliwym ocenom ideologicznym pod kątem wiedzy i poglądów zgodnych z oczekiwanymi. Jeśli któryś z redaktorów w artykułach odbiegał od przyjętych i narzucanych przez PZPR kanonów, wówczas odsuwano go od pracy dziennikarskiej. Ponieważ zdarzały się wśród dziennikarzy osoby mające skłonność do podawania obiektywnych faktów, niekiedy publikowano teksty jak na owe czasy dość odważne. Niemniej jednak szybko „ukracano samowolę” redaktorów tego typu. Bardziej rzeczywisty obraz sytuacji w Polsce można było uzyskać z polskich czasopism wydawanych poza granicami kraju. Do takich należały „Kultura” (Włochy, Francja) $^{22}$ i „Dziennik Związkowy” (USA) ${ }^{23}$. Do najważniejszych tytułów prasowych PRL wydawanych w omawianym czasie w kraju należały: „Trybuna Ludu”, „Trybuna Robotnicza”, „Żołnierz Wolności”, „Polityka”, „Życie Warszawy” oraz „Dziennik Polski” ${ }^{24}$. Każda z wymienionych gazet w podobnym stylu przedstawiała problemy społeczno-polityczne. Jednak ich siła rażenia i propagandowo-dezinformacyjny ton były narzędziem dominującym $\mathrm{w}$ pracy dziennikarskiej.

Stosunki polsko-niemieckie przestawiane w prasie PRL od końca II wojny światowej były uwarunkowane głównie sytuacją polityczną. Wątek antyniemiecki przewijał się $\mathrm{w}$ propagandzie prawie przez cały okres PRL. Zależne od nastrojów politycznych władze Polski mogły eksponować go z rozmaitym natężeniem, dostosowując elementy społecznych stereotypów do aktualnych zapotrzebowań. Propaganda antyniemiecka przybierała na sile z reguły w okresach wewnętrznych kryzysów. Autorzy-propagandziści mieli wówczas jedno zadanie, jakim było wykazanie obywatelom „wroga”. Byli nimi z reguły kapitaliści o poglądach i skłonnościach imperialistycznych, którzy zależnie od kontekstu przybierali postać Niemca z RFN, Amerykanina lub syjonisty ${ }^{25}$.

Pierwsze kontakty polityczne między PRL a NRD nawiązano tuż po powstaniu tego drugiego kraju. W przeważającej mierze dotyczyły one uregulowania spraw granicy polskiej na Odrze i Nysie Łużyckiej ${ }^{26}$. Po podpisaniu układu Polski i NRD w Zgorzelcu w sprawie granicy prasa nazywała ją - w myśl propagan-

${ }^{22}$ Kultura paryska. Twórcy, dzieło, recepcja, oprac. I. Hofman, Lublin 2007, s. 7-15.

${ }^{23}$ W. W i e r z e w s k i, Polskie Chicago, Toruń 2002, s. 5-9.

${ }^{24}$ T. M i e l c z a r e k, Od Nowej Kultury do Polityki. Tygodniki spoleczno-kulturalne i społeczno-polityczne PRL, Kielce 2003, s. 12-18.

${ }^{25}$ Komu groził Niemiec zły, czyli propaganda, „Dziennik Zachodni - Dodatek Bezpłatny”, 28 XI 2013, s. 12.

${ }^{26}$ M. Or ze ch o w s k i, Opinia polska wobec powstania $N R D$, „Śląski Kwartalnik Historyczny" 1972 , z. 2 , s. 10-12. 
dy socjalistycznej - ,granicą przyjaźni”. Określenie to było używane odtąd przez obie strony, a stosunki obu państw przypominały swoistą sinusoidę, której wykres był na ogół w dużym stopniu uzależniony od koniunktury międzynarodowej. Martwa była też „granica przyjaźni”, a lokalne relacje ograniczyły się z początku do manifestacji na mostach, zapalania „ognisk przyjaźni” i wizyt przedstawicieli partii. Ożywienie w kontaktach nastąpiło w latach pięćdziesiątych i sześćdziesiątych, ale wtedy ton narzucały organizacje partyjne województw położonych przy granicy $^{27}$.

T a be 1 a 1

Ważniejsze tytuły prasowe ogólnopolskie i regionalne wydawane w PRL

\begin{tabular}{|l|l|}
\hline Dziennik Bałtycki & Głos Wybrzeża \\
\hline Dziennik Polski & Kurier Lubelski \\
\hline Dziennik Zachodni & Kurier Szczeciński \\
\hline Echo Krakowa & Polityka \\
\hline Express Wieczorny & Przekrój \\
\hline Forum & Słowo Polskie \\
\hline Gazeta Krakowska & Słowo Powszechne \\
\hline Gazeta Wrocławska & Sztandar Młodych \\
\hline Gazeta Współczesna & Trybuna Ludu \\
\hline Gazeta Zielonogórska & Trybuna Robotnicza \\
\hline Głos Pomorza & Tygodnik Powszechny \\
\hline Głos Robotniczy & Żołnierz Wolności \\
\hline Głos Wielkopolski & Życie Warszawy \\
\hline
\end{tabular}

Źródło: opracowanie własne na podstawie T. Mielczarek, Od Nowej Kultury do Polityki. Tygodniki społeczno-kulturalne i społeczno-polityczne PRL, Kielce 2003, s. 12-18, 34-51.

Jak nadmieniono, w czasie powstania muru berlińskiego wszystkie tytuły prasowe wydawane oficjalnie $\mathrm{w}$ PRL milczały na ten temat $\mathrm{i}$ ani raz nie użyto określania „mur berliński”. Szybko powstała sytuacja taka, że w Polsce obywatele doskonale wiedzieli, co władze NRD miały w zamierzeniu, stawiając budowlę, a władze z kolei zdawały sobie sprawę z tego, że obywatele po części znają prawdę. Zamiast pojęcia „mur berliński” używano w zamian określeń typu „nadzwyczajne środki bezpieczeństwa”, „strefa bezpieczeństwa” itp. Interesujące wydaje się to, że według informacji pochodzących z prasy każde z tych działań spotkało się z pełną aprobatą, a nawet entuzjazmem ze strony Niemców. Propagandowy ton w prasie stroniący od nazywania rzeczy po imieniu nie znikał. Kon-

${ }^{27}$ J. K o c h a n o w s k i, Socjologiczny zwiad po otwarciu granic PRL - NRD, ,Polski Przegląd Dyplomatyczny" 2001, t. I, nr 2, s. 230-231. 
teksty polskie związane z powstaniem muru berlińskiego w sierpniu $1961 \mathrm{r}$. w prasie PRL dalekie były od jakiejkolwiek wolności słowa. Teksty artykułów i notatek informacyjnych wypełniały sformułowania charakterystyczne dla języka propagandy komunistycznej. Miało to odzwierciedlenie w przedstawieniu $\mathrm{w}$ prasie sytuacji, jaka zaistniała w Berlinie przed i po 13 sierpnia $1961 \mathrm{r}^{28}$

Zarówno z prasy ogólnokrajowej, takiej jak „Polityka”, „Słowo Powszechne” czy „Trybuna Ludu”, jak i lokalnej, typu „Ilustrowany Kurier Polski”, „Gazeta Pomorska” i „Dziennik Wieczorny”, nie można było w pełni dowiedzieć się prawdy. Ich czytelnik skazany był prawie w $100 \%$ na przyswajanie treści propagandowych mających wykazać słuszność poglądów socjalistów. Kierunki propagandy prasowej prawie zawsze starały się kreować pozytywny obraz stosunków PRL z NRD, a także rzekome poparcie obywateli PRL dla NRD i polityki przezeń prowadzonej. Usiłowano urabiać opinię publiczną, że popieranie NRD i polityki lansowanej przez jej władze bardzo zbliża Polskę z NRD i ma wpływ na umacnianie socjalizmu. W rzeczywistości wielu obywateli PRL i NRD było całkowicie odmiennego zdania i w ogóle nie czytało oficjalnej prasy. Władze Polski, doskonale zdające sobie sprawę z takiego stanowiska wielu obywateli, nie poruszały w artykułach prasowych kwestii masowych ucieczek do RFN oraz popierania ich przez Polaków. Nie wspomniano nawet w ani jednym zdaniu tematu powstania muru berlińskiego.

W nieco bardziej odważny sposób pisano w wydawanej na Zachodzie „Kulturze". Biorąc pod uwagę, że gazeta ta wydawana była poza granicami PRL, autorzy artykułów mogli sobie pozwolić na komentowanie sytuacji politycznej bez ingerencji ze strony cenzury. Stanowili oni przeciwwagę dla propagandzistów oficjalnych czasopism posługujących się dalekimi od prawdy informacjami. Gazeta ta nierzadko starała się „wyprostowywać” zniekształcone wiadomości podawane przez uchodzących za poważnych redaktorów pracowników gazet sterowanych przez władze komunistyczne w Polsce ${ }^{29}$.

Trzeba pamiętać, że przeciętny obywatel, dla którego głównym nośnikiem wiadomości była któraś z wydawanych na terenie PRL gazet, był pewien, że sytuacja na terenie Berlina uległa zaognieniu wskutek niechęci mocarstw zachodnich do zawarcia układu pokojowego z Niemcami i podjęcia jakichkolwiek rozmów, które miały doprowadzić do rozwiązania w Berlinie sytuacji czy wręcz podżegania do kolejnego sporu. W „Polityce” kilka dni po oficjalnej dacie powstania muru berlińskiego pisano o możliwym konflikcie zbrojnym. Równolegle

${ }^{28}$ T. S c h o 1 z e, Falk Blask, Halt! Grenzgebiet! Leben im. Schatten der Mauer, Berlin 1992, s. 23-26.

${ }^{29}$ Vide: Polska - Niemcy 1961, „Kultura. Szkice - opowiadania - sprawozdania”, marzec 1961, s. 91-102; W. K o zło w sk i, „Przegląd Niemiecki”, styczeń-luty 1962, s. 194-197; i d e m, „Przegląd Niemiecki”, czerwiec 1962, s. 87-92; Jak rewidowano rewizjonizm, „Przegląd Niemiecki”, wrzesień 1962, s. 107-115. 
starano się kreować wizerunek ZSRR jako kraju stojącego na straży pokojowego rozwiązania kwestii berlińskiej ${ }^{30}$. Propaganda PRL przedstawiała RFN jako kraj prowokujący antagonizmy i prący do nieporozumień. Najbardziej smutne w tym było to, że strona pomawiająca i inicjująca podziały oficjalnie podawała się za strażnika praworządności. Kroki „strażnika”, jakim był ZSRR, musiały być niezbędne, ale jedynie w odniesieniu do bezpieczeństwa Niemców mieszkających na obszarze NRD i innych krajów orbity radzieckiej ${ }^{31}$. Spychanie odpowiedzialności za nieporozumienia w Berlinie na Zachód znakomicie oddaje cytat $\mathrm{z}$ tygodnika „Polityka” mówiący o tym, że (zgodnie z powiedzeniem niemieckim) „,nie jada się posiłku tak gorącego, jakim się go warzyło"32.

Oficjalna propaganda prasowa w PRL praktycznie na łamach wszystkich gazet popierała działania władz enerdowskich w odizolowaniu społeczeństwa tego kraju od RFN. Z tego względu, w myśl przesłanek ideologii socjalistycznej, każde $\mathrm{z}$ czasopism $\mathrm{w}$ podobnym tonie pisało o solidaryzowaniu się społeczeństwa polskiego ze „wschodnioniemieckim sąsiadem”. W duchu socjalistycznym pisano o tworzeniu frontu porozumienia i przeciwstawiania się ,imperialistom". W prasie PRL Niemcy Zachodnie, odizolowane murem od NRD, postrzegano jako wroga, który stoi po stronie wszystkich krajów zachodnich - przeciwników bloku wschodniego. Jedynie z „Kultury” wydawanej we Francji można było się dowiedzieć prawdy o manipulacjach komunistów, braku rzetelnych informacji w prasie peerelowskiej oraz monopolizowaniu przez nich rozmaitych obszarów oddziaływania na opinię społeczną w Polsce odnośnie do spraw Niemiec ${ }^{33}$. De facto w prasie tej napisano zgodnie z prawdą, że kryzys berliński powstały w związku z wybudowaniem muru i podziałem Niemiec nie sprawił, że wszystkim zależało na zjednoczeniu Niemiec tylko dla zjednoczenia. Chodziło wówczas tylko i wyłącznie o włączenie całych Niemiec do jednego z bloków - zachodniego lub wschodniego $^{34}$. Poza tym poruszano kwestie zachodniej granicy Polski na Odrze i Nysie Łużyckiej, co stało się przedmiotem wielu dyskusji przy okazji kryzysu sierpniowego wywołanego budową muru berlińskiego. Propaganda prasy NRD i PRL usiłowała posunąć się nawet do tego, że granica ta zostanie uznana przez państwa Zachodu. Określenie, że Zachód zaakceptuje zachodnią granicę PRL, nie było równoznaczne z tym, że uzna też granicę wschodnią NRD. Tego typu manipulacje pojawiały się w wielu artykułach prasowych bogatych w propagandę ${ }^{35}$.

\footnotetext{
${ }^{30}$ Berliński sierpień, „Polityka”, 26 VIII 1961, s. 8.

${ }^{31}$ Goracy spór o Berlin, „Trybuna Ludu”, 18 VIII 1961, s. 2-3.

${ }^{32}$ Berliński sierpień..., s. 8.

${ }^{33} \mathrm{Z}$. B r z e z i ń s k i, W. G r i f f i t h, $O$ nową politykę Europy Wschodniej, „Kultura. Szkice - Opowiadania - Sprawozdania", lipiec-sierpień 1961, s. 9.

${ }^{34}$ J. M i e r o s z e w s k i, Walka o Niemcy, „Kultura. Szkice - Opowiadania - Sprawozdania”, wrzesień-październik 1961, s. 92.

${ }^{35}$ Ibidem.
} 
$\mathrm{Z}$ racji tego, że NRD i Polska znajdowały się w bloku socjalistycznym, w czasie kryzysu propaganda prasowa sierpniowego ukierunkowana została na kwestie związane z obopólną współpracą państw. Pisano o delegacjach NRD w PRL i polskich w Niemczech Wschodnich ${ }^{36}$, wymianie gospodarczej oraz współpracy kulturalnej. Były to zabiegi mające na celu odwrócenie uwagi społecznej od muru berlińskiego i przypadków niezadowolenia z sytuacji obecnych wśród obywateli Polski i NRD. Sporo miejsca zajmowała propaganda o współpracy PZPR z SED i zbliżeniu ideologicznym partii. Spotkania ich przedstawicieli, delegacje i konferencje propagandowo cementowały udział partii w rozwoju i utrwalaniu socjalizmu. Na myślącym obywatelu informacje te nie robiły jednak większego wrażenia. Niemałą część w prasie polskiej zajmowały windowane na wyrost statystyki odnośnie do wymiany handlowej ${ }^{37}$, co miało unaocznić, że współpraca krajów socjalistycznych opiera się na przemyślanych i rozsądnych decyzjach. Taka propaganda miała również czytelnikom pokazać, że płynna współpraca krajów socjalistycznych stanowi przykład dla innych oraz że blok socjalistyczny odgrywa ważną rolę w relacjach międzynarodowych ${ }^{38}$.

Do jednych z najważniejszych zadań po 16 sierpnia $1961 \mathrm{r}$. stojących przed prasą propagandową PRL należało kompromitowanie ,przeciwników politycznych", czyli w tym przypadku RFN. Wyolbrzymiając fakty, usiłowano udowodnić, że władze tego kraju na czele z kanclerzem Willym Brandtem stosują ostre praktyki represyjne i radykalne kroki wobec partii komunistycznej SED. Działalność komunistów w RFN nie była z oczywistych względów mile widziana, ale „Trybuna Ludu” w propagandowy sposób podała, że Niemcy Zachodnie stronią od rzekomego „postępu” i zabraniają na swoim terytorium działań partii i organizacji „rozwojowych"39. Podobnie postępowały dzienniki lokalne, pisząc o prowokacyjnym zachowaniu kanclerza Brandta ${ }^{40}$.

Stopniowo zainteresowanie sprawą Berlina i podziału Niemiec zeszło na dalszy plan. W stosunkach PRL-NRD pojawiły się zadrażnienia o charakterze politycznym. W dodatku w miarę perspektywy wyjazdów Polaków do Czechosłowacji, Węgier i Bułgarii (nie mówiąc o wyjazdach na Zachód) tym bardziej słabło zainteresowanie socjalistycznym NRD. Prasa polska nie wspomniała o tym ani jednym zdaniem. W połowie lat sześćdziesiątych z PRL do NRD wyjechało 51,8 tys.

${ }^{36}$ Delegacja rządowa NRD, „Trybuna Ludu”, 17 VIII 1961, s. 1.

${ }^{37}$ Polska - NRD. Rozwój wspótpracy ekonomicznej, „Trybuna Ludu”, 30 VIII 1961, s. 2.

${ }^{38}$ Szybki wzrost produkcji przemystowej obozu socjalistycznego, „Trybuna Ludu”, 17 VIII 1961, s. 2.

${ }^{39}$ Represje władz Berlina Zachodniego przeciwko postępowym organizacjom, „Trybuna Ludu", 16 VIII 1961, s. 1.

${ }^{40}$ Wokót sprawy Berlina - prowokacyjne przemówcie Brandta, „Gazeta Pomorska”, 17 VIII 1961, s. 1. 
turystów polskich, a pięć lat później - 32,5 tys. ${ }^{41}$ Mimo że od kilku lat oficjalny ton w prasie mówił o zrównoważonym rozwoju NRD i PRL jako państw socjalistycznych, gros obywateli Polski wyjeżdżających do NRD twierdziło, że ten kraj znacznie wyprzedza w rozwoju gospodarczym PRL $^{42}$. Było to $w$ pewnym sensie odzwierciedlenie stosunków politycznych na linii Warszawa-Berlin. Chociaż 15 marca 1967 r. podpisano układ o przyjaźni, współpracy i pomocy wzajemnej, nie zabrakło nieporozumień na tle politycznym między PZPR i SED. Chodziło tutaj głównie o relacje z RFN, zwłaszcza o ich powstrzymanie. Prasa polska jednak nadal nie podawała, jak naprawdę wyglądają owe stosunki, wciąż usiłując zachować oficjalny ton propagandy mówiący o rozwijającej się współpracy ${ }^{43}$. Polegała ona na często praktykowanych po powstaniu muru berlińskiego $\mathrm{w}$ latach 1961-1970 spotkaniach przedstawicieli władz partyjno-państwowych. Mimo schematyczności stanowiły one metodę pobudzania wzajemnych relacji rozwijających się w ściśle określonych przez nie ramach i dających dodatkowe możliwości dynamizacji współpracy ${ }^{44}$.

Trzeba dodać, że swego rodzaju rewolucję w stosunkach PRL z NRD wniosła dekada lat siedemdziesiątych. W obu krajach dokonała się zmiana władz w grudniu 1970 r. I sekretarzem partii rządzącej w PRL został Edward Gierek, a pół roku później w NRD - Erich Honecker ${ }^{45}$. Sekretarze ci, wywodzący się z tego samego pokolenia, usiłowali uchodzić za bardziej nowoczesnych, postępowych i otwartych na świat niż ich ortodoksyjni poprzednicy. Polepszyły się wówczas również uwarunkowania zewnętrzne. Na przełomie lat sześćdziesiątych i siedemdziesiątych kroki w celu odprężenia po interwencji ZSRR w Czechosłowacji w 1968 r. dotarly do Europy Wschodniej. Pod koniec 1970 r. został podpisany układ o normalizacji stosunków między PRL a RFN. Coraz bardziej intensywne relacje RFN z NRD doprowadziły do podpisania umowy w sprawie ruchu tranzytowego do Berlina Zachodniego. Wywarło to naturalnie duży wpływ na kontakty Berlina z Warszawą. Po obu stronach Odry wypracowywano nowe koncepcje wzajemnych stosunków. Główny nacisk położono na umacnianie sojuszu politycznego, współpracę w sferze gospodarczej, naukowo-technicznej

${ }^{41}$ PRL-NRD. Sojusz i wspótpraca. 30-lecie PRL. 25-lecie NRD, Warszawa 1974, s. 201.

${ }^{42} \mathrm{~B}$. S t e f a ń c z y k, Wplyw otwartej granicy PRL - NRD na równowagę rynkowa $w$ Polsce, „Kwartalnik SGH” 2011, nr 4 (16), s. 138.

${ }^{43}$ NRD i PRL wspieraja socjalizm, „Trybuna Ludu”, 19 VIII 1967, s. 2.

${ }^{44}$ Delegacja NRD przybyla do Polski, „Trybuna Robotnicza”, 20 VIII 1962, s. 1; Wspótpraca PRL z NRD gwarancją dobrosąsiedzkich stosunków, „Polityka”, 17 III 1963, s. 3; Kolejna delegacja władz PRL odwiedziła NRD, „Słowo Polskie”, 22 X 1964, s. 2; Wspótpraca NRD z PRL, „Żołnierz Wolności”, 20 VI 1965, s. 1; Dobrosasiedzkie stosunki PRL i NRD, „Głos Robotniczy”, 22 IV 1966, s. 2; Wzajemne relacje NRD i PRL, „Dziennik Polski”, 12 III 1967, s. 1; Wspótpraca PRL z NRD, „Forum”, 13 V 1968, s. 4; NRD i PRL w obozie socjalistycznym, „Głos Wielkopolski”, 22 VII 1969, s. 2.

${ }^{45}$ J. R üh 1 e, G. H o 1 z w e i ß i g, op. cit., s. 81-89. 
i kulturalnej. Usiłowano również dążyć do zbliżenia społeczeństw i zmiany dotąd praktykowanych stereotypów ${ }^{46}$.

W sprawie roli muru berlińskiego komuniści przeliczyli się ze swymi założeniami i już 9 listopada 1989 r. runął symbol komunizmu i podziału. Jednak jeszcze przez wiele lat pozostał on w pamięci ogromnej liczby osób. W związku z 20. rocznicą jego upadku w 2009 r. przeprowadzono w Polsce specjalną ankietę. Według niej mur berliński kojarzył się Polakom w 23\% z upadkiem komunizmu, w $17 \%$ z podziałem Niemiec, a w $12 \%$ z samym komunizmem. Większość uważała jego upadek za symbol przemian z lat 1980-1989 na terenie Europy Środkowo-Wschodniej ${ }^{47}$.

MirosŁAW ROMAŃSKI

\section{Social-political situation within the period of building the Berlin Wall according to Polish press releases}

The article deals with the matter of social-political relations between GDR and the People's Republic of Poland within the period of building the Berlin Wall in 1961 from the point of view of the Polish press issued officially and unofficially which has been little studied so far.

It shows huge differences in opinions and reliability of transferring press information between the official press and the one issued in the West. It involves mainly the relationship of Polish press towards the Berlin Wall and methods and directions of shaping the public opinion.

Capturing the subject character of propaganda that was used in showing the relations between GDR and Federal Republic of Germany was also important. That is why analysing the chosen press titles issued within the mentioned period was also necessary for that reason, although it can be stated that defining those relations was not an easy task due to the poor sources (only several press articles).

${ }^{46}$ J. K o c h a n o w s k i, op. cit., s. 231-232.

${ }^{47}$ Badanie z okazji 20-lecia upadku muru berlińskiego TNS OBOP dla Przedstawicielstwa Komisji Europejskiej w Polsce, oprac. A. Zadrożna, Warszawa 2009, s. 5. 